\title{
The secreted metabolome of HeLa cells under effect of Crotamine, a cell- penetrating peptide from a rattlesnake using NMR-based metabolomics analyses
}

Monika Aparecida Coronado ${ }^{1+*}$,Fábio Rogério de Moraes $^{2+}$, Bruna Stuqui ${ }^{3,4+}$, Marília Freitas Calmon ${ }^{3}$, Raphael Josef Eberle ${ }^{1,4}$, Paula Rahal ${ }^{3}$, Raghuvir Krishnaswamy Arni2*

${ }^{1}$ Institute of Biological Information Processing (IBI-7: Structural Biochemistry), Forschungszentrum Jülich, Jülich, 52428, Germany.

${ }^{2}$ Multiuser Center for Biomolecular Innovation, Departament of Physics, Instituto de Biociências Letras e Ciências Exatas (Ibilce), Universidade Estadual Paulista (UNESP), São Jose do Rio Preto-SP, 15054-000, Brazil

${ }^{3}$ Laboratory of Genomic Studies, Departament of Biology, Instituto de Biociências Letras e Ciências Exatas (Ibilce), Universidade Estadual Paulista (UNESP), São Jose do Rio Preto-SP, 15054-000, Brazil

${ }^{4}$ Instituto Federal de Educação, Ciência e Tecnologia de São Paulo - IFSP, Brazil.

${ }^{5}$ Institut für Physikalische Biologie, Heinrich-Heine-Universität Düsseldorf, Universitätsstraße, Düsseldorf, 40225, Germany.

* Correspondence: m.coronado@fz-juelich.de (M.A.C.); raghuvir.arni@unesp.br (R.K.A.); Tel.: +49 $246161-9505$ (M.A.C.); +55 017 3221-2460 (R.K.A.)

† These first authors contributed equally to this work.

Abstract: Sequestering and reprogramming of cellular metabolism represents one of the principal hallmarks several cells. Antimicrobial peptides have been shown to exhibit selective anticancer activities. In this study, the secreted metabolome of HeLa cells under action of the antimicrobial peptide Crotamine was evaluated. Although, Crotamine has been shown to be selective for highly proliferating cells and is able to extend the in vivo lifespan. The present study using a cell line of cervical cancer, HeLa cells provide insights into how Crotamine acts in cell metabolism. NMR spectroscopy was used to identify and quantify relative metabolite levels, which are associated with Crotamine uptake. Statistical analysis reveals that Crotamine dramatically affects metabolites related to glycolysis, metabolism and biosynthesis of amino acids and pyruvate metabolism. The developed machine learning model is found to be robust by ROC curve analysis, suggesting that the metabolic state of HeLa cells treated with Crotamine is different from the control samples. To account for metabolite levels, it is suggested that Crotamine would have to act on glycolysis, which, in turn, affects several other metabolic pathways, such as, glutathione metabolism, TCA cycle and pyruvate metabolism. The observed metabolic changes shed light into the mode of Crotamine function.

Keywords: Cell-penetrating peptide; Crotamine; Anticancer; Metabolomics. 


\section{Introduction}

Diverse factors such as exposure to carcinogens, viruses, ionizing radiation, chemicals as well as genetic disorders such as cell line mutations trigger the onset of cancer [1]. The Global Burden of Disease (GBD) estimated in 2015, there were 17.5 million cancer cases worldwide and for 2018 it was estimated to result in 9.6 million deaths. The statistics indicate that the incidence of cancer increased about $33 \%$ between 2005 and 2015 [2].

A non-enveloped small (8000bp) DNA-virus with circular double-stranded DNA, has been implicated in causing genital warts and cancer. More than 40 years ago, Human Papillomavirus (HPV) was implicated in causing different human neoplastic lesions [3] and currently, 200 HPV types including cutaneous and mucosal HPV types have been characterized. Cervical cancer (CC) is certainly the most common cancer among women causing significant morbidity and mortality worldwide [4-6]. In 2012, it was estimated that more than 527,000 new cases with an $85 \%$ occurrence rate was registered in less developed regions resulting in and more than 265,000 deaths with $87 \%$ of them from less developed countries [6,7]. In 2018, it was estimated for almost 570,000 and the numbers of deaths was more than 311,000 worldwide with an estimation to increase more than 35\% from 2018 to $2040[8,9]$. At the global level, one in 68 women develops CC in their life-times, the occurrence is higher in developing countries, with 1 in 24 women presenting CC symptoms, and is significantly lower in highly developed countries, where 1 in 115 women developed CC during their lifetimes [2].

According to the National Cancer Institute of Brazil (INCA), the estimated number of new cases of CC for each year of the biennium 2018-2019 was estimated with a risk of 16,370 cases per 100.000 women in Brazil. It represents the seventh neoplasm more frequent in female population in the world ranking, and the fourth cause of women's mortality by cancer in Brazil [10].

Proteins, peptides and enzymes from animals of different species are being tested for use in cancer therapies and many active secretions produced by animals have been employed in the development of new drugs to treat diseases such as hypertension and cancer. Snake venom toxins have contributed significantly to the treatment of many medical conditions [11] and a host of studies cite the anti-cancer potential of snake venoms $[12,13]$.

Since treatment of cancer is a major challenge and many of the currently used therapies are prohibitively expensive and often trigger undesirable secondary reactions. Molecules isolated from snake venoms have been demonstrated to retard and inhibit the growth of cancerous cells and hence have been the focus of research [12]. Crotamine, extracted from the venom of the Brazilian rattlesnake, Crotalus durissus terrificus, is a highly basic (pI 10.3), low molecular weight (42 kDa), non-enzymatic and, non-cytolytic cell-penetrating 
peptide (CPP) [14-16] that can cross the cellular lipid barrier [17-19]. It also exhibits other activities such as: antimicrobial activity [20,21], selectivity for highly proliferating cells [20,22]; inhibits tumor growth [23], and it is also potentially interesting as an individual therapeutic agent since it possesses the ability to transport proteins, peptides, nucleic acids and, perhaps, even entire genes across the cellular membrane $[17,24-28]$.

Selective cytotoxicity of Crotamine in tumor cells has been reported: experiments using Crotamine as an inhibitor resulted in a significant decrease of tumor growth and, mice with tumors showed an increase in survival rates $[23,29]$ and it has also been demonstrated to possess anti-tumoral activity in cell cultures and animal models [22,23,29,30]. Experiments using in vitro model are more feasible and practical to assess the potential effect of molecules and to understand the underlying mechanisms of physiological processes. Understanding the cellular responses of Crotamine may provide metabolic information on the reactions of biological systems at the molecular level. The biological interactions in cellular pathways can be elucidated based by the analysis of cell lines using NMR-based metabolomics foot printing assays, to screen promising drugs, and is also effective in in vitro screening for identifying significant metabolite changes in response to the administration of diverse molecules [31-33].

In the present study, we utilized an integrated metabolomics approach to systematically investigate the response of Human cervical adenocarcinoma cells (HeLa cell line) using Crotamine as the mediator. Based on the analysis of the metabolic pathway, we identified changes of the cell line pattern. $1 \mathrm{H}$ NMR spectroscopy coupled with pattern recognition and biochemical network analysis was used to characterize the metabolic footprint profile of HeLa cells.

\section{Materials and Methods}

\subsection{Cell Line}

Human cervical adenocarcinoma cell line (HeLa) was kindly provided by Luisa Lina Villa (Department of Radiology, Center on Translational Oncology Investigation, São Paulo State Cancer Institute, São Paulo University, Brazil). Cell lines were cultured in Dulbecco's modified Eagle medium (DMEM) (Gibco Life Technologies, Grand Island, NY, USA) supplemented with 10\% heat inactivated fetal bovine serum (FBS), penicillin $(50 \mathrm{U} / \mathrm{mL})$, and streptomycin $(0.05 \mathrm{mg} / \mathrm{mL})$. Cells were incubated at $37^{\circ} \mathrm{C}$ with $5 \%$ CO2. 


\subsection{MTT Assay}

Colorimetric MTT assay was used to evaluate the cytotoxicity in 96-well plates and the medium containing Crotamine at concentrations of $6,8,10,12,14,16$, and $20 \mu \mathrm{M}$ was added to each well containing $1 \times 104$ cells. After 4, 12, and $24 \mathrm{~h}$ of incubation with Crotamine, $100 \mu \mathrm{L}$ of medium containing 3-(4,5dimethylthiazol-2-yl)-2,5-diphenyl tetrazolium bromide (MTT) (1 mg/mL) (Sigma-Aldrich) was added to each well. After $30 \mathrm{~min}$ of incubation, the medium was removed, and the formazan crystals were solubilized by incubation for $10 \mathrm{~min}$ in $100 \mu \mathrm{L}$ of DMSO (Sigma-Aldrich). Absorbance of each well was determined at $570 \mathrm{~nm}$. Each experiment was performed in triplicate and in three independent assays.

\subsection{Crotamine treatment and Metabolite Extraction}

For cell seeding, HeLa cells were cultured in serum-starved medium. After 24 h, Crotamine was added to the supplemented culture medium (containing 10\% FBS and antibiotics) at concentrations of 10 $\mu \mathrm{M}$. Crotamine treatment concentration was chosen based on the results of the MTT assay. To avoid contamination in the cell culture, filter sterilization (using a Millipore filter with a pore size of $0.22 \mu \mathrm{m}$ ) of the medium containing Crotamine was applied before introducing the medium to the cell culture. After 24 hours of Crotamine incubation, the medium was submitted to footprint metabolomics studies. The control group received only serum starved medium by $24 \mathrm{~h}$.

\subsection{Nuclear Magnetic Resonance Spectroscopy}

Nuclear Magnetic Resonance (NMR) measurements from sample cultures were performed in a Bruker AVANCE III HD (Germany), operating at $600 \mathrm{MHz}$ for $1 \mathrm{H}$ equipped with a triple resonance cryoprobe. The standard NOESYPR1D pulse sequence was used with a recycle delay of $2 \mathrm{~s}$, a mixing time of $100 \mathrm{~ms}, 16$ scans (four dummy scans), collected in $32 \mathrm{k}$ complex data points and a spectral width of 20 ppm. Each free induction decay measurement (FIDs) was multiplied by an exponential function with $1 \mathrm{~Hz}$ line-broadening, followed by Fourier transformation in the Bruker TopSpin 3.2.5 (Bruker Biospin, Germany). Reference in each spectrum was performed internally by setting the lactate methyl doublet at $1.31 \mathrm{ppm}$. Finally, the residual water region (4.5-5.0 ppm) was deleted from the dataset.

Furthermore, specific regions were formerly subjected to integral calculation, after metabolite identification, for relative concentration over samples. For assisting metabolite identification, selected samples were used for collecting 1H, 13C Heteronuclear Single Quantum Coherence spectroscopy (HSQC). 


\subsection{Statistical Analysis}

Data was organized following MetaboAnalyst guidelines [34] and its web server was used for analysis. First, data was Pareto scaled (mean centered and divided by the square root of the standard deviation), and subsequently, Principal Component Analysis (PCA), Partial Least Square Discriminant Analysis (PLS-DA) and its orthogonal version (OPLS-DA) were performed. First, the complete spectra (excluding the solvent region) were uploaded for evaluating control and treated metabolic differences by means of PCA, PLS-DA and OPLS-DA score plots. Significant signals related to high absolute loadings were subject to metabolite identification. Specific metabolite signals quantified by their integrals were reorganized and uploaded to MetaboAnalyst for further analysis. Univariate t-test and fold change analysis were used to compare relative metabolite levels between control and Crotamine treated HeLa cells. Boxplots and t-test p-values were used to check differences in metabolite levels. Also, PCA, PLS-DA and OPLS-DA were repeated with this reduced dataset to confirm if the used metabolites were able to keep the degree of difference between control and Crotamine-treated cell lines. Furthermore, machine learning classification methods, Random Forest and Support Vector Machine (SVM) were used to check if the developed models were successful in predicting whether cells were from a control or Crotamine-treated sample.

To assess the robustness of the developed model with respect to metabolite levels following Crotamine treatment, Receiver Operating Characteristic (ROC) curves for three different classification algorithms, as available in MetaboAnalyst at Biomarker Analysis module was used. For each model, the web-server uses a Monte-Carlo cross validation scheme where $66 \%$ of the data is used to assess feature importance and build the model itself, whereas the remaining 33\% are used for validation and performance measurement. This process is then repeated using different metabolites sets. Metabolite importance is assessed according to the frequency of occurrence of a particular metabolite is selected to compose a classification model.

\subsection{Metabolite Identification}

Metabolites were manually identified using Chenomx profiler (version 8.1, Chenomx Inc., Canada) by matching resonances of random spectra. Cross-peaks were identified in the TOCSY spectra as well as signals from the 1H, 13C-HSQC. Expected TOCSY and HSQC signals were retrieved from the Human Metabolome Data Bank [35]. 


\subsection{Pathway Analysis}

Genome-scale metabolic models have long been used for gaining insights into the response of metabolic pathways of a variety of different stimuli in context to an organism, a key concept in the system biology approach [36]. HeLa cell lines metabolic model was generated by using RNA-seq data and evaluated with metabolome mapping, showing interesting results for the identification of cancer related metabolites in different cell lines [37]. In this study, HeLa cells metabolic model were uploaded into MetExplore web server [38] and the observed metabolite levels were used to get insights into the metabolic path-ways that were changed by the uptake of Crotamine.

\section{Results}

\subsection{Viability of HeLa cells in response to the exposure of Crotamine}

Crotamine was purified following the procedure of Coronado et al. (2013) [16] and used for cell viability assays. Experimental control cells retained their viability at all analyzed incubation times. After 4, 12 and $24 \mathrm{~h}$ of incubation with all the tested concentrations of Crotamine, HeLa cells demonstrated viabilities greater than $70 \%$ (Figure 1). Viability of HeLa cells decreased with increasing Crotamine concentration; however, the concentrations used in this work demonstrated low cytotoxicity. From these results, the $10 \mu \mathrm{M}$ concentration and $24 \mathrm{~h}$ incubation were chosen, as the results showed great cell viability of around $90 \%$.

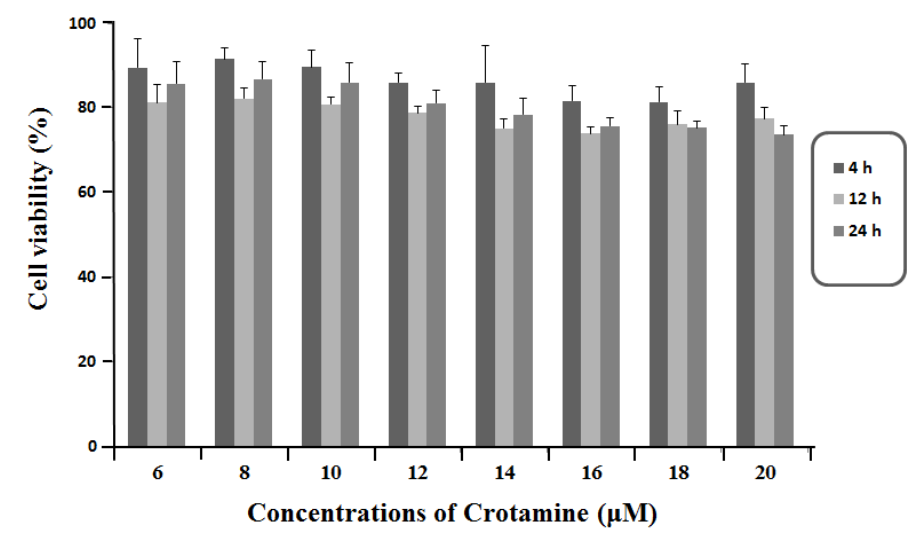

Figure 1. Analysis of the cellular effects of Crotamine on HeLa cells viability. Cell viability assay investigated after 4, 12 and $24 \mathrm{~h}$ of incubation with Crotamine at concentrations of $6,8,10,12,14,16$, and $20 \mu \mathrm{M}$.

\subsection{Secreted metabolic profile of HeLa cells}

Since the highest cell viability obtained on HeLa cells was after $24 \mathrm{~h}$, we decide to evaluate the secreted metabolomic profiling on HeLa cells treated with $10 \mu \mathrm{M}$ Crotamine and to compare this with the results for untreated cells. 
For the present study, metabolic foot printing was been used to characterize the metabolic changes of HeLa cells subjected to Crotamine. Intensities from NMR spectra were examined, and spectral bins were manually selected to exclude noisy and solvent regions.

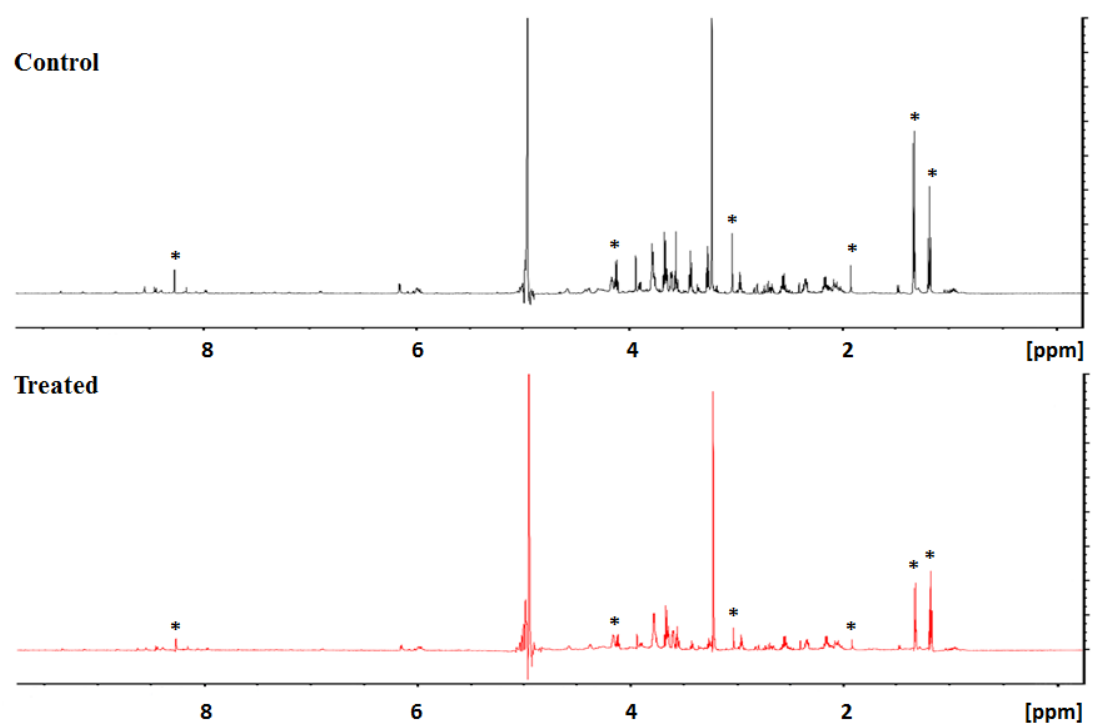

Figure 2. NMR spectrum comparison. NMR spectrum comparison between control and treated sample.

Following the treatment of the Crotamine NMR profile of HeLa cells, the observed metabolic differences between control and treated cells (Figure 2-asterisk), indicated that Crotamine induced alterations in the metabolism of HeLa cells.

The analysis of the spectra shows the presence of signals (i) leucine, isoleucine, valine, ethanol, lactate, pyruvate, lysine, pyroglutamate, threonine, and glucose in the spectra region from $0.0 \mathrm{ppm}$ to 5.5 ppm, (ii) 1-methylhistidine, tyrosine, phenylalanine, and formate in the spectra region from 7 ppm to 8.5 ppm (Table1; Figure 3).

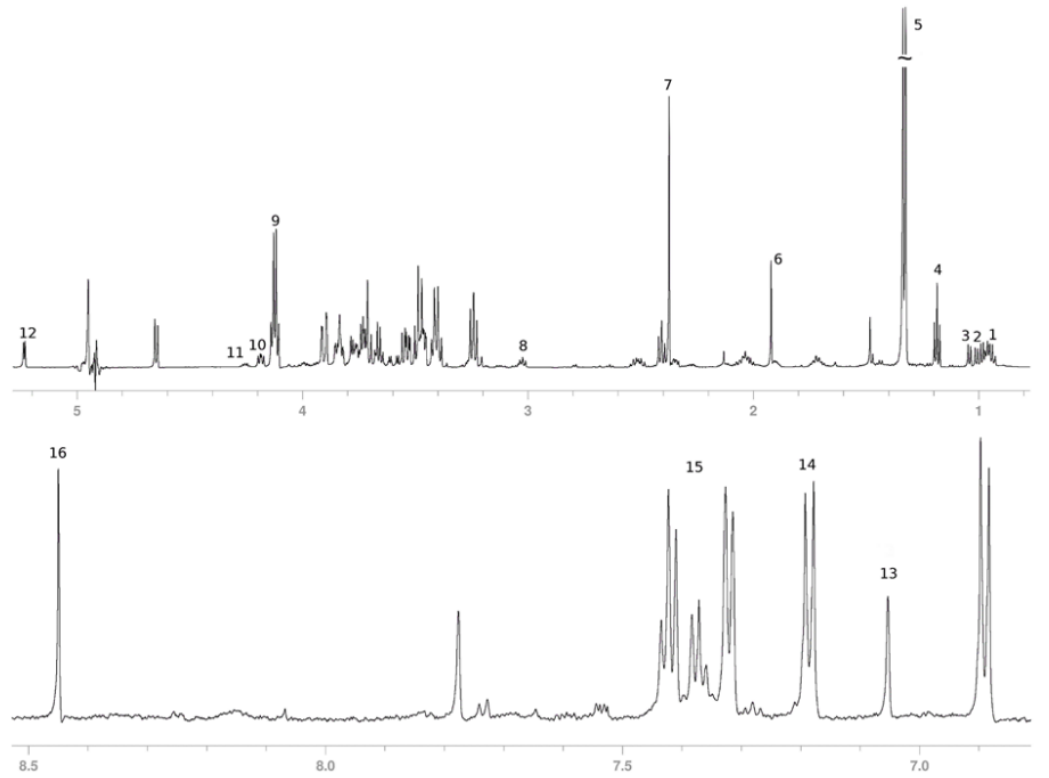

Figure 3. Sample NMR spectrum. NMR spectrum showing signals for: 1 - Leucine; 2 -Isoleucine; 3 - Valine; 4 - Ethanol; 5 and 9 Lactate; 6 - Acetate; 7 - Pyruvate; 8 - Lysine; 10 - Pyruglutamate; 11 - Threonine; 12 - Glucose; 13 - 1-Methylhistidine; 14 - Tyrosine; 15 - Phenylalanine; 16 - Formate. 
Table 1. List of HeLa metabolic pathways affected by Crotamine uptake, using a p-value of Fisher's test $>5 \%$.

\begin{tabular}{|c|c|c|c|}
\hline Pathway & Coverage & $\begin{array}{l}\text { \# Metabolites } \\
\text { matched }\end{array}$ & $\begin{array}{c}\text { Right tailed } \\
\text { Fisher-test }\end{array}$ \\
\hline Transport of extracellular metabolites & 2.13 & 13 & $7.76 \mathrm{E}-11$ \\
\hline Protein degradation & 12.73 & 7 & $1.04 \mathrm{E}-10$ \\
\hline Aminoacyl-tRNA biosynthesis & 11.11 & 7 & $2.81 \mathrm{E}-10$ \\
\hline Artificial reactions & 8.97 & 7 & 1.31E-09 \\
\hline Transport to mitochondria & 3.56 & 9 & 9.39E-09 \\
\hline Transport lysosomal & 5.26 & 7 & $5.71 \mathrm{E}-08$ \\
\hline Glycolysis/Gluconeogenesis & 7.81 & 5 & $1.01 \mathrm{E}-06$ \\
\hline Transport peroxisomal & 3.88 & 4 & $2.38 \mathrm{E}-04$ \\
\hline Pyruvate metabolism & 6.12 & 3 & 4.35E-04 \\
\hline $\begin{array}{l}\text { Valine, Leucine and Isoleucine } \\
\text { metabolism }\end{array}$ & 4.76 & 3 & $9.13 \mathrm{E}-04$ \\
\hline Glutathione metabolism & 5.56 & 2 & $5.58 \mathrm{E}-03$ \\
\hline Tyrosine metabolism & 5.56 & 2 & $5.58 \mathrm{E}-03$ \\
\hline $\begin{array}{l}\text { Phenylalanine, tyrosine and tryptophan } \\
\text { biosynthesis }\end{array}$ & 2.5 & 3 & $5.80 \mathrm{E}-03$ \\
\hline Transport Golgi apparatus & 3.64 & 2 & 1.27E-02 \\
\hline Cysteine and methionine metabolism & 3.03 & 2 & $1.80 \mathrm{E}-02$ \\
\hline Glycine, serine and threonine metabolism & 2.3 & 2 & 3.02E-02 \\
\hline
\end{tabular}

2.3. Crotamine induced metabolic variation in HeLa cells. (Multivariate data analysis)

Multivariate data analysis was employed to analyze the changes caused by Crotamine on HeLa cells and to identify the possible metabolic pathway involved.

PCA, PLS-DA and OPLS-DA score plots show well selected controls and the treated groups in the 95\% confidence interval, indicate significant metabolic changes in HeLa cells because of the Crotamine treatment. Principal component analysis (PCA) of the 1H NMR spectra showed a clear discrimination between HeLa cell line before and after $10 \mu \mathrm{M}$ treatment with Crotamine (Figure 4a). To obtain information on the types of metabolites responsible for the class separation, the orthogonal projection to latent structure with discriminant analysis (OPLS-DA) was conducted with the corresponding NMR data from the cell 
group. As illustrated in Figure $4 \mathrm{~b}$, the control and Crotamine-treated groups could be clearly distinguished in the OPLS-DA score plot.

a) FULL SPECTRA

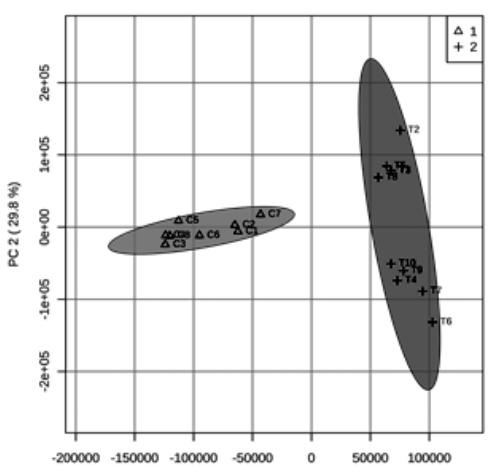

PC 1(49.6\%)
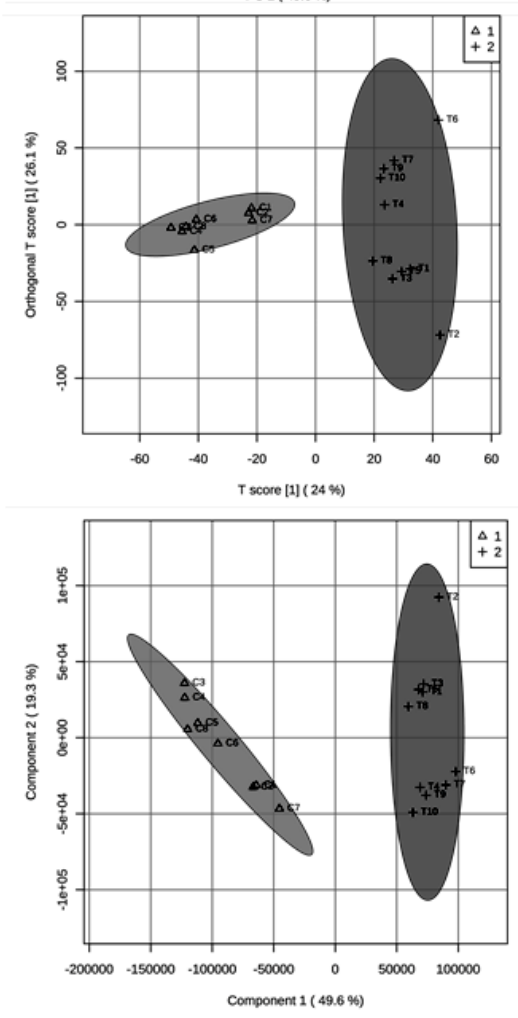

b) METABOLITE CONC.
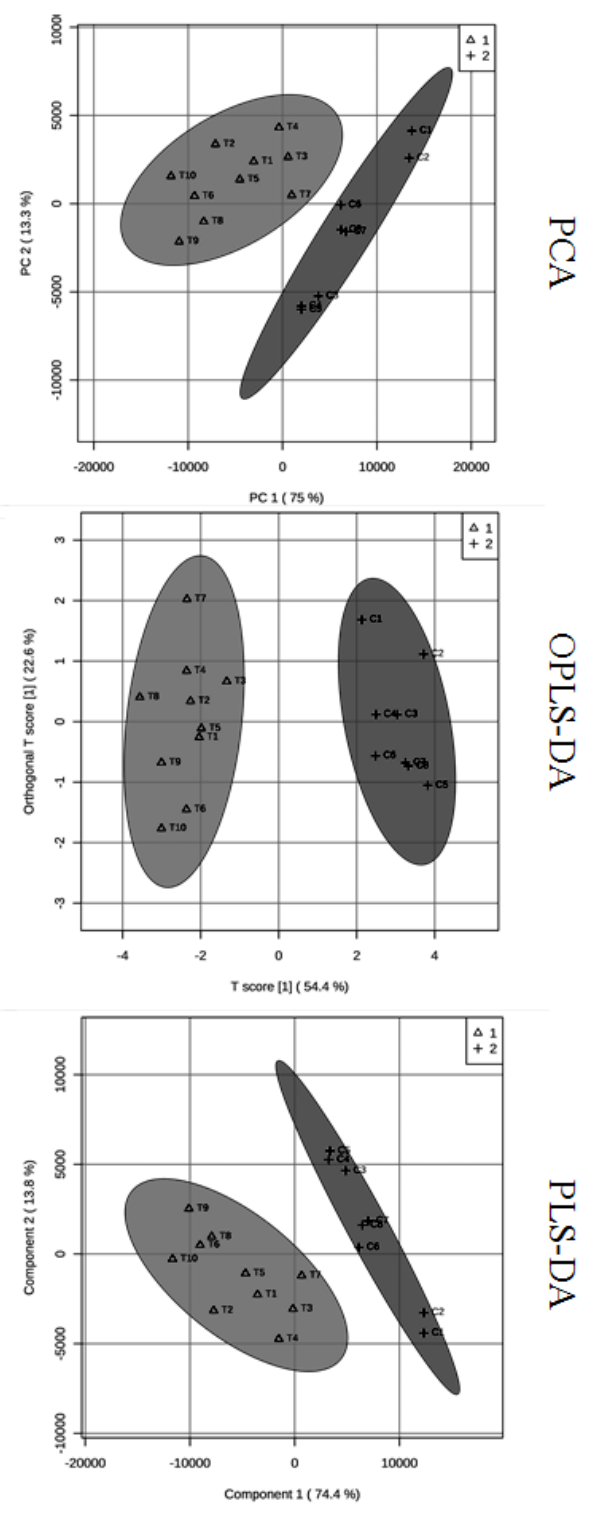

Figure 4. PCA, PLS-DA and OPLS-DA score plots. Principal component analysis (a), orthogonal partial least square discriminant analysis (b) and partial least square discriminant analysis score plots performed for full spectra bins and integral signals for selected metabolites.

Additionally, signals that satisfy the requirements of possessing a Welch-test p-value lower than $5 \%$, a fold change in log scale higher than 1.2 or lower than 0.8 and have high VIP score from PLS-DA loadings were selected (Figure 4c). These signals were used to metabolite identification as performed by 
matching chemical shifts and the scalar coupling in the Chenomx NMR software package and 1H,13CHSQC signals. A total of 15 metabolites, presented in the Table 1 and in Figure 3, were considered relevant for distinguishing between control and Crotamine treated cell cultures. Their levels encountered in Crotamine-treated and control samples were measured using the integral module in TopSpin 3.2 for isolated signals of each metabolite (Fig. 4 Metabolite conc.). The measured values were scaled in MetaboAnalyst to identify which metabolic pathways are involved. The tool suggests the most relevant pathways by uploading the discriminatory compounds that were significantly influenced by Crotamine treatment. Results are displayed in figure 5 as boxplots.

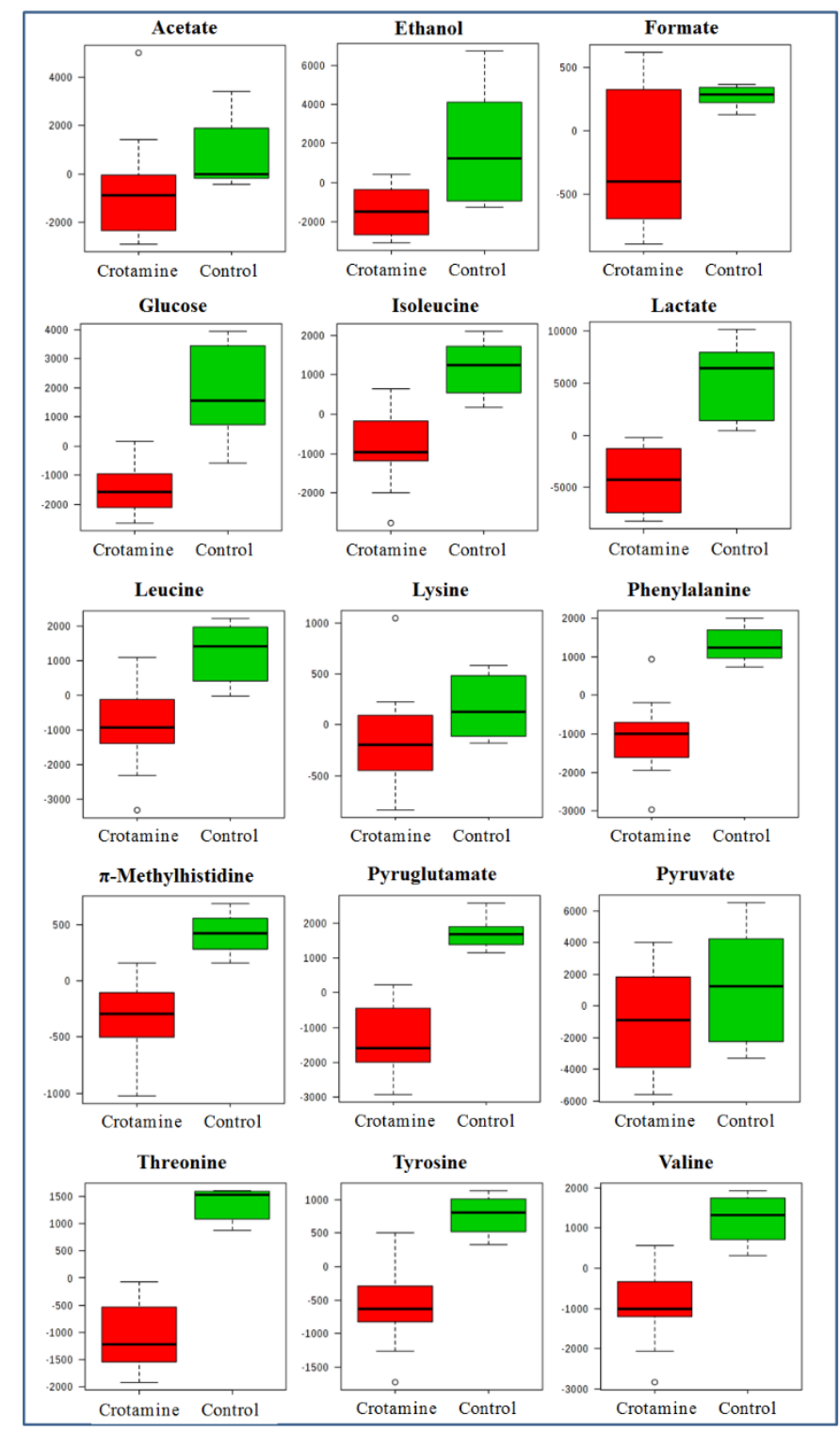

Figure 5. Metabolite levels in Crotamine-treated and control samples. Levels of each metabolite found to be important for distinguishing between Crotamine-treated and control samples. Values were evaluated from integrated isolated signals for each metabolite presented in NMR spectra and scaled in MetaboAnalyst. 
In our study, the stress-related metabolic variations include the decreases of acetate, ethanol, formate, glucose, etc. The decreased levels of amino acids such as isoleucine, leucine, lysine, phenylalanine, threonine, tyrosine, and valine indicate an inhibitor of protein metabolism in response of Crotamine. Lactate and acetate release are closely correlated with the variance of the glucose utilization mainly due to cytosolic pyruvate production in glycolysis.

Each of the models developed to analyze the data provides an overview of the metabolite enrichment set as presented in figure $6 \mathrm{a}$ and ranked according to metabolite importance. Classification probabilities for each sample following the Monte-Carlo cross validation is shown in figure 6b. Perfect classification is achieved for both SVM (3 metabolite levels used) and PLS-DA (2 metabolite levels used). These results indicate that the metabolite levels used in the models can potentially applied to differentiate between the metabolic states of control HeLa cells and following Crotamine treatment.
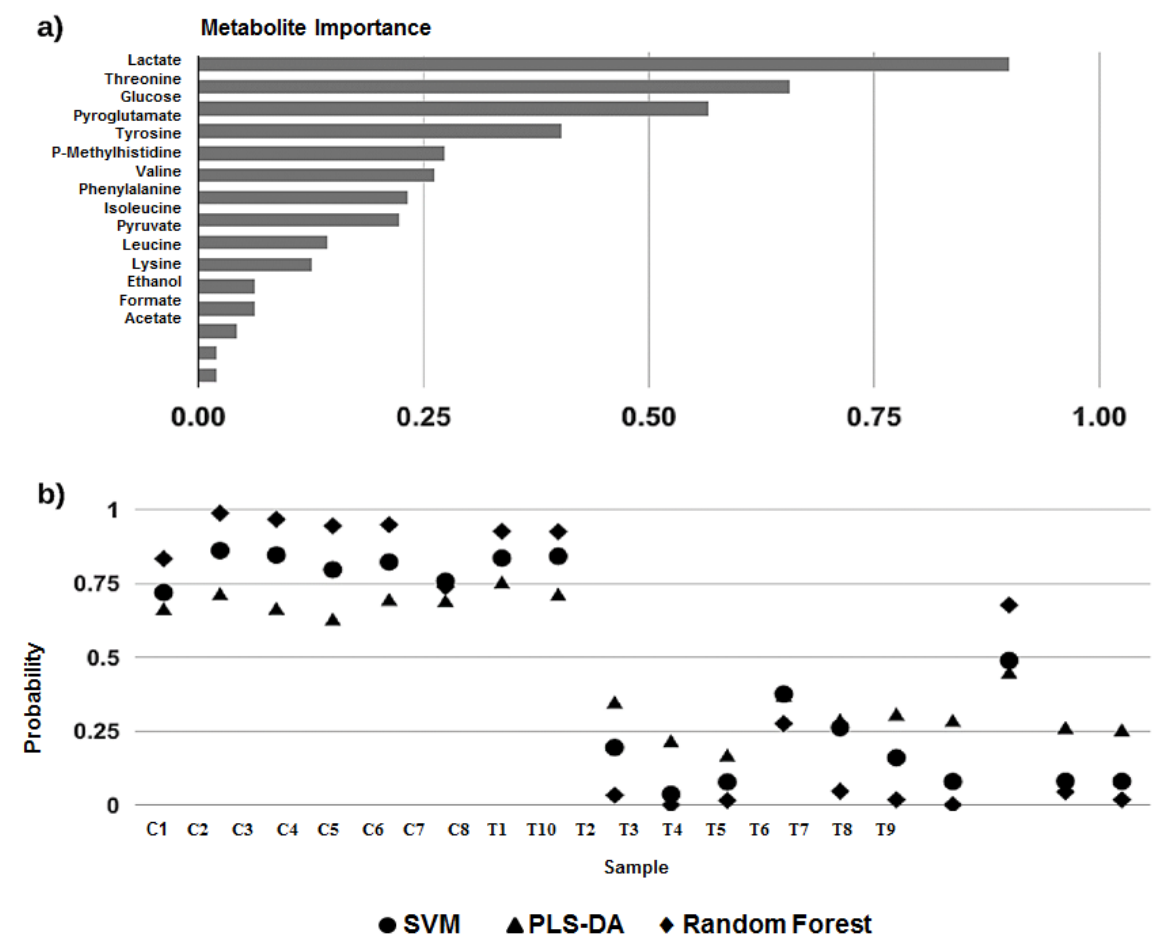

Figure 6. Metabolite Importance and Classification Models. Metabolite importance measured as the average of used frequency in classification models SVM, PLS-DA and Random Forest (a). Classification probabilities for each sample tested in Monte-Carlo cross validation by classification models SVM, PLS-DA and Random Forest (b).

\section{Discussion}

In order to identify the pathway and to identify the roles in cancer development, the observed metabolite levels were analyzed using genome scale metabolic models for HeLa cells that were uploaded into the MetExplore web server and based on the metabolome analysis module, the metabolite levels 
measured by NMR were set and a list of affected pathways were retrieved using a right tailed Fisher's test (Table1). Since some metabolite levels were reduced in the Crotamine treated samples, transport reactions can be recovered to be altered from non-essential metabolites and between different compartments within cell. Due to the observed changes in the amino acids levels, protein degradation and aminoacyl-tRNA biosynthesis pathways are evaluated by MetExplore analysis. Artificial reactions are a set of chemical reactions and account for biomass content (amino acids, lipids and nucleotides), vitamins derivatives and cofactors available in the model and, for instance, are not of special importance. Interestingly, the metabolic pathways found to be affected in HeLa cell treated with Crotamine are all interlinked as observed (Fig. 7).

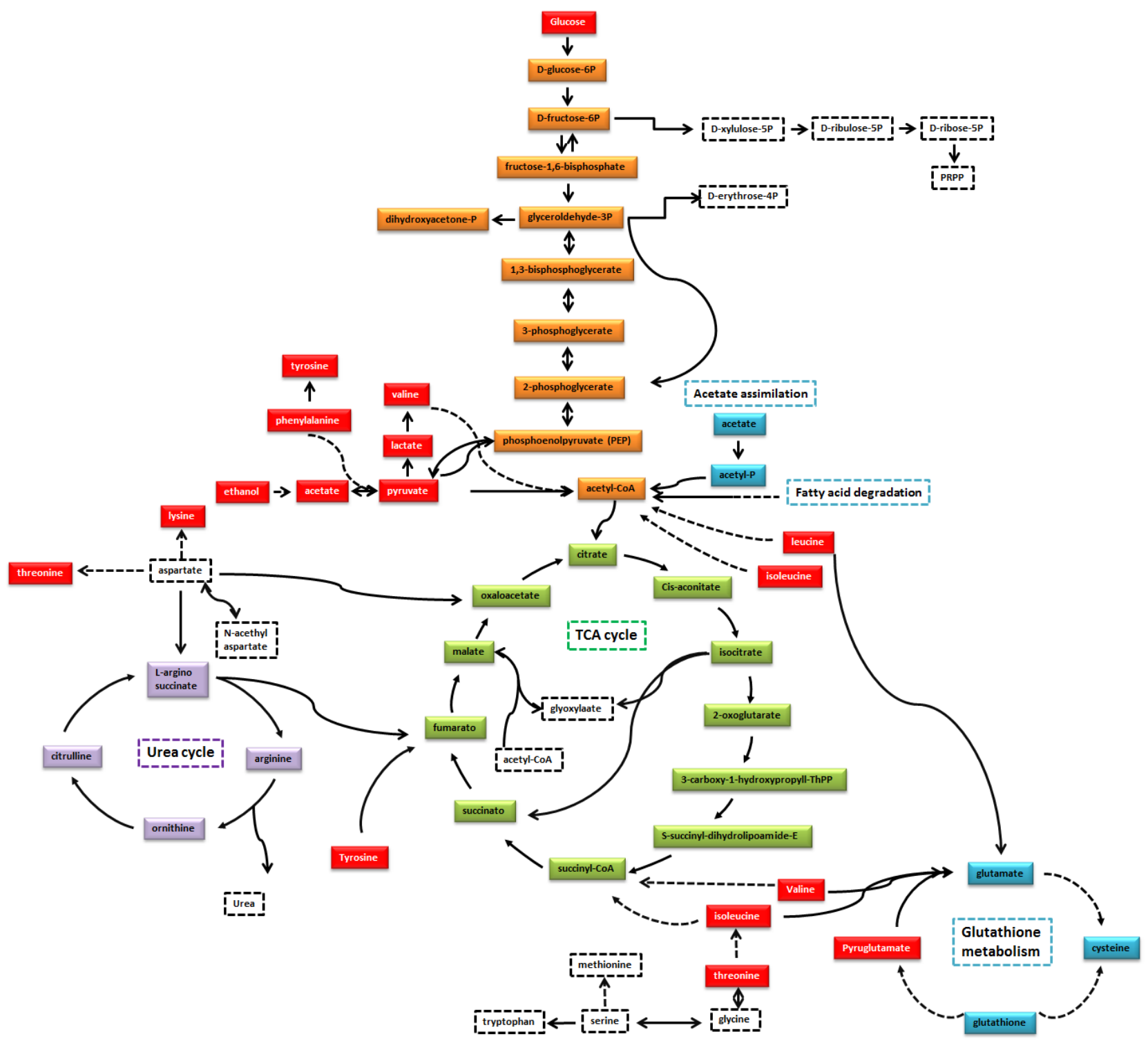

Figure 7. Important pathways affected by Crotamine in HeLa cells. Crotamine-treated samples were found to have altered levels of the metabolites in red. Important pathways retrieved by genome-scale metabolic modeling are shown. Straight lines show direct biochemical reactions while dashed lines represent biochemical steps not shown. 
As mentioned earlier, many metabolites were affected by treatment with Crotamine. Furthermore, lactate is found to be the most used metabolite of the classification (Figure 6a). Independently of oxygen, most cancer cells produce their energy by taking up glucose and producing lactate, it was observed by Otto Warburg in the 1920s, in Warburgs effect [39-42], which increase the levels of lactate. The reduced lactate levels in Crotamine-treated samples are in line with drug effects that target glycolysis [43]. The same point holds for pyruvate levels, since one is the precursor to the other, and it is the end-point in glycolysis (Figure 7). Many studies indicate that tumors cells present the capacity to produce energy in the aerobic oxidation of glucose [40,44]. Furthermore, mitochondrial metabolism is fundamental in the process of cancer cell proliferation [45]. The TCA cycle can be supplied by other sources using fatty acid and amino acids as substrate to maintain ATP production in cancer cells [40,46].

Reduction in glucose levels, the third metabolite in the rank of importance, is observed in treated samples. Increase in glucose uptake may be achieved by overexpressing a set of proteins known as glucose transporters [47-49], which indicate that cells are changing their metabolic state in order to increase energy production that is affected by Crotamine. Glucose can be switched on by acetate, to support the biosynthesis of fatty acids and lipids, as demonstrated in tumor-like tissue culture condition [44,50,51]. One rescued acetate molecule can produce acetyl-CoA to synthesize fatty acid or sterols, to acetylation of histones, or to promote oxidation to generate additionally $~ 12$ units of ATP, all of this process at the cost of a single ATP [52]. Some studies address the importance of acetate in cancer development [53-56]. One alternative source of carbon can be provided by acetate, as well as by glutamine if the access to the glucosederived from acetyl-CoA is compromised by hypoxia or mitochondrial dysfunction $[44,56]$.

Dependent of an acetyl-CoA synthetase2 (ACSS2), studies using metabolomics demonstrated that cancer-cell can capture acetate molecules to use as a carbon source [53,57]. An acetate, when ligated to CoA is the most central and dynamic metabolite in intermediary metabolism (Fig.7).

It is well documented that cancer cells generate energy differently than normal cells $[53,58,59]$. The process that healthy cells get energy is very complex and requires oxygen molecules; however, the current knowledge indicates that this does not occur in cancer cells $[44,60,61]$. The metabolic pathway used for cancer cells to produce energy was demonstrated to be more primitive [44,47,60-61]. The less efficient process, the Warburg effect has been studied extensively. In the 1920s, several experiments performed by Otto Warburg demonstrated that cancer cells generate energy via fermentation, similar to the process observed in yeast, even when there is a sufficient amount of oxygen available to break down glucose [39, 62]. Using fermentation, which is less efficient, the cancer cells should use more glucose to produce the same amount of energy, suggesting that malignant cells have to rely on other sources for metabolism, like 
fats and amino acids [63]. Tyrosine is one of the sources that cancer prefers but is rarely used by normal healthy cells. Some in vitro studies demonstrate that the restriction in the availability of tyrosine, as also methionine, and phenylalanine affects the signaling pathway, and induces apoptosis in some cancer cells lines [64-66].

Many studies have shown that the restriction of specific amino acids modulates glucose consumption and the changes are closely related to glucose metabolism. In prostate cancer cells the carbohydrate metabolism is modulated by the restriction of amino acid, as shown by Fu et al., which causes modification in glucose metabolism, thereby leading to cell death and apoptosis $[64,67]$.

Phenylalanine, one of the reduced molecules in our study is an essential amino acid and its hydroxylation produces tyrosine. The ketogenic component, which in fact, is one important component of the tricarboxylic acid (TCA) cycle, is produced by the degradation of tyrosine to acetoacetate and fumarate (Fig.7). Oxaloacetate, which is converted from the fumarate, can be directed to the gluconeogenesis pathway. There are five amino acids entering the TCA cycle via pyruvate, these are: alanine, glycine, serine, cysteine, and tryptophan. In Crotamine-treated samples we did not observed any modification in these amino acids. However, the other amino acids that yield acetyl-CoA and/or acetoacetyl-CoA, like as lysine, phenylalanine, tyrosine, leucine, and isoleucine are affected by Crotamine. On the other hand, threonine is one amino acid that can be converted in glycine and play a pivotal role in one-carbon metabolism and nucleotide synthesis [60]. However, this is an amino acid that cannot be synthesized by humans; all demand is fulfilled by uptake. Mammalian cells require threonine as an essential amino acid [68]. Threonine plays a key role in cancer cell growth and proliferation [69]. Cell death and reduction in methylation of some histone are results from the shortage of threonine in cell cultures $[60,68]$. There is a sequence of simultaneous events; tyrosine reduction, probably reduce the glutamate synthesis, which automatically reduce its PTM (post-translational modification), it means, the reduction of pyroglutamate, the cyclic form of glutamate.

Following the described metabolite changes, the cyclic amino acid pyroglutamate is encountered at the N-terminus of some protein and biological peptides [70], which is often involved in stabilizing the protein by making it more resistant to chemical or enzymatic degradation [71,72]. Pyroglutamate is an intermediate in glutathione metabolism, whereas, glutathione (GSH) plays an important role in a multitude of cellular processes. In cancer cells it is particularly relevant in the progression and regulation of carcinogenic mechanism. GSH is crucial to control the reactive oxygen and, its deficiency leads to a susceptibility to oxidative stress, involved in cancer progression [73]. The excess of reactive oxygen leads to cell damage as well as cancer development [74], the antioxidants often help in protecting against cancer 
cell formation. On the other hand, GSH is converted to a diverse compound by glutathione-S-transferase, which is responsible in regulating the pathway of mitogen-activated protein (MAP) kinase, responsible for cell survival, as well as being associated with anticancer drug resistance [75]. The probable perturbation of the GSH metabolism by Crotamine opens the possibility of regulating the cellular response. Since, either glutamate or GSH are observed in the NMR spectra, decreased pyroglutamate levels only suggest that Crotamine treatment alters the intracellular redox balance.

Tumor cells can reprogram metabolism in ways that support growth. Following our Crotaminetreated HeLa cells, the BCAAs (Branched-Chain Amino Acid); leucine, isoleucine, and valine, which are essential nutrients for cancer growth, and are present in elevated concentrations impact protein synthesis and degradation [76,77]. Tumor cells uptake BCAA amino acids for protein synthesis or alternatively, oxidizes them to obtain energy [78]. BCAAs are converted into their branched-chain alpha-keto acids by two aminotransferases; one present in the cytosolic space [Branched-chain aminotransferase1 (BCAT1)] and a mitochondrial [branched-chain aminotransferase2 (BCAT2)], the process occurs when the amino group is transferred to the alpha-ketoglutarate, generating glutamate [78,79], affecting the glutathione metabolism, as described earlier. The reduction level of these amino acids in Crotamine treated cells may interfere in the BCAA degradation, and consequently in glutathione metabolism.

In the present study, the lysine concentration decreased under Crotamine treated cells, and we presumed it was being used for cell survival and proliferation. Modifications in lysine are an important functional feature, which regulates cancer development. Dependent of acetyl-CoA, acetylation controlled multiple metabolic processes and lysine acetylation is $[80,81]$ a reversible process, which provide a functional diversity to the protein. When instability in the acetylation is occurring, the stability of the internal environment of the cell can be turned off, as showed in cancer cells [82,83]. We could not test the action of the Crotamine in the acetylation processes; however, lysine is an indispensable amino acid for cell maintenance. The decreased level of lysine in HeLa-treated cell, suggests that this is due to the action of Crotamine in the acetylation process. Histidine is an amino acid that can undergo methylation. 1methylhistidine, a decreased metabolite in Crotamine treated sample, is a methylated form of histidine, which is frequent in human muscles and urine. 1-methylhistidine is involved in histidine and beta-alanine metabolism [84], the latter, presented altered levels in estrogen receptor for breast cancer subtypes, as well in cancer tissue [84]. Few studies deal with the role of this metabolite in cancer cells.

Formate is a metabolite produce in mammals, being a source of single-carbon group, used for purine synthesis, as well as in methylation [85]. Produced in different tissue from a variety of substrate, it can be synthesized during the catabolism of tryptophan. Formate production is important for a regulatory 
mechanism, in other words, it is important for the methylation of the DNA, RNA, and proteins [85]. The amount of formate in cancer cells seems to be two times more, compared to normal cells [86,87], and its decrease in the presence of Crotamine, may restrict the supply of the single-carbon group. To conclude, acetate is related to ethanol degradation, and it is further metabolized to acetyl-CoA.

\section{Conclusions}

Following glucose uptake, cancer cell lines preferentially use glycolysis for ATP production, leading to pyruvate and lactate production. Pyruvate is directly linked to the TCA cycle and to valine, leucine and isoleucine metabolism, which in turn, is related to glutathione metabolism and to pyroglutamate levels. Glutathione is the precursor of glycine and thus, glycine, serine, and threonine metabolism are linked to the glutathione and valine, leucine and isoleucine pathways, threonine is metabolized in two ways to be converted in pyruvate. Phenylalanine is the precursor of both pyruvate and tyrosine, which in turn, may be converted to fumarate, a component of the TCA cycle. Finally, aspartate is converted to lysine, threonine and oxaloacetate, also from the TCA cycle.

It is possible to track all observed metabolites following the arrows in figure 7, starting from glucose. Thus, the present results rise the hypothesis that Crotamine may influence the conversion of glucose to pyruvate. Following glucose uptake, it may be consumed by glycolysis, to produce glycogen or may be used in the pentose phosphate pathway [39]. The observation that glucose levels in the medium is reduced in Crotamine-treated sample, indicates that its uptake is increased when compared to untreated HeLa cells. Nevertheless, both pyruvate and lactate, that are synthesized within cell and their surplus are secreted to the medium, are also found to be reduced. This suggests that Crotamine function may be involved in impairing glycolysis. By impairing glycolysis and pyruvate production, it could also bias the TCA cycle, glutathione metabolism and amino acids bio-synthesis and metabolism, as shown in figure 7. However, due to top-down nature of metabolomics approaches, data are inconclusive about how this could be achieved. Crotamine is known to interact with DNA and it could be affecting specific gene expression pathways related to glycolysis or even promoting gene expression in the glycogen synthesis pathway, and in regulating glucose usage in cellular metabolism.

Snake venoms are an interesting source of molecules and are potentially relevant for use in a wide range of biological and clinical applications. Crotamine is a versatile peptide with a variety of biological properties, such as; cell penetration with carrier properties, interaction with DNA and RNA and, as subject of the present study, inhibition of tumor growth and development. The exact mechanism by which 
Crotamine functions as an anticancer peptide is unclear. In this metabolomics foot printing approach, the levels of certain metabolites were observed to be different following Crotamine treatment of HeLa cells indicating that specific pathways were affected. These results provide an indication of Crotamine function and its mechanism of action in the inhibition of cancer cell growth. Specifically, Crotamine impairs glycolysis, and interferes with other pathways involved glutathione metabolism, the TCA cycle and amino acid biosynthesis and metabolism.

A total of 15 metabolites were changed in the treated sample and provides potential information in cancer progression. Further investigation is needed to validate these initial findings.

Author Contributions: Conceptualization, M.A.C.; methodology, M.A.C. and F.R.M.; validation, M.A.C., F.R.M., R.J.E., B.S. and M.F.C.; formal analysis, M.A.C., F.R.M., B.S. and M.F.C.; investigation, M.A.C., F.R.M. and B.S.; resources, P.R. and R.K.A.; writing-original draft preparation, M.A.C., F.R.M. and B.S.; writing - review and editing, M.A.C., F.R.M., B.S., M.F.C., R.J.E., P.R. and R.K.A. All authors have read and agreed to the published version of the manuscript.

Funding: This research was supported by grants from CNPq [Grant numbers 435913/2016-6, 401270/20149, 307338/2014-2, 150444/2017-6], FAPESP [Grant numbers 2015/13765-0, 2015/18868-2, 2016/08104-8; 2009/53989-4], CAPES and PROPe UNESP.

Institutional Review Board Statement: Not applicable.

Informed Consent Statement: Not applicable.

Data Availability Statement: The data that support the findings of this study are available on request from the corresponding author, [M.A.C].

Acknowledgments: "We authors would like to dedicate our work to the researchers who gave up their research due the negligence of the Brazilian Federal Government."

Conflicts of Interest: The authors declare no conflict of interest.

\section{References}

1. Hassanpour, S.H.; Dehghani, M. Review of cancer from perspective of molecular. J. Cancer Res. Pract. 2017, 4, 127e129. https://doi.org/10.1016/j.jcrpr.2017.07.001

2. Global Burden of Disease Cancer Collaboration. Global, Regional, and National Cancer Incidence, Mortality, Years of Life Lost, Years Lived with Disability, and Disability Adjusted Life-years for 32 Cancer Groups, 1990 to 2015. A Systematic Analysis for the Global Burden of Disease Study. JAMA Oncol. 2017, 3, 524-548. https://doi.org/10.1001/jamaoncol.2016.5688

3. Lorenzi, A.T.; Syrjänen, K.J.; Longatto, F.A. Human papillomavirus (HPV) screening and cervical cancer burden. A Brazilian perspective. Virol. J. 2015, 12, 112. https://doi.org/10.1186/s12985-015-0342-0 
4. Syrjänen, K.; Syrjänenm S. Papillomavirus Infections in Human Pathology. 1st ed. NY, USA: J.Wiley\& Sons. 2000.

5. Coelho, F.R.G.F.; Fregnani, J.; Zeferino, J.H.T.G.; Villa, L.C.; Federico, L.L.; Novaes, M.H.; Costa, P.E.R.S.; Câncer do Colo do Útero. São Paulo,Brazil: Tecmedd. 2008.

6. Ferlay, J.; Soerjomataram, I.; Dikshi, R.; Eser, S.; Mathers, C.; Rebelo, M.; Parkin, D.M.; Forman, D.; Bray, F. Cancer incidence and mortality worldwide: Sources, methods and major patterns in GLOBOCAN 2012. Int. J. Cancer. 2015, 136, E359-E386. https://doi.org/10.1002/ijc.29210

7. Ervik, M.; Lam, F.; Ferlay, J.; Mery, L.; Soerjomataram, I.; Bray, F. Cancer Today. Lyon, France: International Agency for Research on Cancer. Cancer Today. 2015. Available from: http://gco.iarc.fr/today. 8. Ferlay, J.; Colombet, M.; Soerjomataram, I.; Mathers, C.; Parkin, D.M.; Piñeros, M.; Znaor, A.; Bray, F. Estimating the global cancer incidence and mortality in 2018: GLOBOCAN sources and methods. Int. J. Cancer. 2019, 144, 1941-1953. https://doi.org/10.1002/ijc.31937

9. Bray, F.; Ferlay, J.; Soerjomataram, I.; Siegel, R.L.; Torre, L.A.; Jemal, A. Global cancer statistics 2018: GLOBOCAN estimates of incidence and mortality worldwide for 36 cancers in 185 countries. CA: Cancer J. Clin. 2018, 68, 394-424. https://doi.org/10.3322/caac.21492

10. INCA. Coordenação de Prevenção e Vigilância Brasil. Rio de Janeiro: Ministério da Saúde; Instituto Nacional de Câncer - Estimativa. 2018. https://www.inca.gov.br/tipos-de-cancer/cancer-do-colo-do-utero. Accessed on 10 Jan 2019.

11. Cushman, D.W.; Ondetti, M.A. History of the design of captopril and related inhibitors of angiotensin converting enzyme. Hypertension 1991, 17, 589-92. https://doi.org/10.1161/01.hyp.17.4.589

12. Vyas, V.K.; Brahmbhatt, K.; Bhatt, H.; Parmar, U. Therapeutic potential of snake venom in cancer therapy: current perspectives. Asian Pac. J. Trop. Biomed. 2013, 3, 156-162. https://doi.org/10.1016/S22211691(13)60042-8

13. Shanbhag, V.K.L. Applications of snake venoms in treatment of cancer. Asian Pac. J. Trop. Biomed. 2015, 5, 275-276. https://doi.org/10.1016/S2221-1691(15)30344-0

14. Nicastro, G.; Franzoni, L.; De Chiara, C.; Mancin, A.C.; Giglio, J.R.; Spisni, A. Solution structure of crotamine, a Na+ channel-affecting toxin from Crotalus durissus errificus venom. FEBS J. 2003, 270, 19691979. https://doi.org/10.1046/j.1432-1033.2003.03563.x

15. Fadel, V.; Bettendorff, P.; Herrmann, T.; de Azevedo, W.F. Jr; Oliveira, E.B.; Yamane, T.; Wüthrich, K. Automated NMR structure determination and disulfide bond identification of the myotoxin crotamine from Crotalus durissus terrificus. Toxicon 2005, 46, 759-767. https://doi.org/10.1016/j.toxicon.2005.07.018

16. Coronado, M.A.; Gabdulkhakov, A.; Georgieva, D.; Sankaran, B.; Murakami, M.T.; Arni, R.K.; Betzel, C. Structure of the polypeptide crotamine from the Brazilian rattlesnake Crotalus durissus terrificus. Acta Crystallogr. D Biol. Crystallogr. 2013, 69(Pt 10), 1958-64. https://doi.org/10.1107/S0907444913018003

17. Fawell, S.; Seery, J.; Daikh, Y.; Moore, C.; Chen, L.L.; Pepinsky, B.; Barsoum, J. Tat-mediated delivery of heterologous proteins into cells. Proc. Natl. Acad. Sci. 1994, 91, 664-668. https://doi.org/10.1073/pnas.91.2.664

18. Vives, E.; Brodin, P.; Lebleu, B. A truncated HIV-1 Tat protein basic domain rapidly translocates through the plasma membrane and accumulates in the cell nucleus. J. Biol. Chem. 1997, 272, 16010-16017. https://doi.org/10.1074/jbc.272.25.16010

19. Schwarze, S.R.; Ho, A.; Vocero-Akbani, A.; Dowdy, S.F. In vivo protein transduction: delivery of a biologically active protein into the mouse. Science 1999, 285, 1569-1572. https://doi.org/10.1126/science.285.5433.1569 
20. Yamane, E.S.; Bizerra, F.C.; Oliveira, E.B.; Moreira, J.T.; Rajabi, M.; Nunes, G.L.; de Souza, A.O.; da Silva, I.D.; Yama-ne, T.; Karpel, R.L.; Silva, P.I. Jr; Hayashi, M.A. Unraveling the antifungal activity of a South American rattlesnake toxin crotamine. Biochimie 2013, 95, 231-40. https://doi.org/10.1016/j.biochi.2012.09.019

21. Kerkis, I.; Hayashi, M.A.; Prieto da Silva, A.R.; Pereira, A.; De SáJúnior, P.L.; Zaharenko, A.J.; RádisBaptista, G.; Kerkis, A.; Yamane, T. State of the art in the studies on crotamine, a cell penetrating peptide from South American rattlesnake. Biomed. Res. Int. 2014, 675985. https://doi.org/10.1155/2014/675985

22. Kerkis, A.; Kerkis, I.; Rádis-Baptista, G.; Oliveira, E.B.; Vianna-Morgante, A.M.; Pereira, L.V.; Yamane, T. Crotamine is a novel cell-penetrating protein from the venom of rattlesnake Crotalus durissus terrificus. FASEB J. 2004, 18, 1407-9. https://doi.org/10.1096/fj.03-1459fje

23. Pereira, A.; Kerkis, A.; Hayashi, M.A.; Pereira, A.S.; Silva, F.S.; Oliveira, E.B.; Prieto da Silva, A.R.; Yamane, T.; Rádis-Baptista, G.; Kerkis, I. Crotamine toxicity and efficacy in mouse models of melanoma. Expert Opin. Investig. Drugs 2011, 20, 1189-1200. https://doi.org/10.1517/13543784.2011.602064

24. Kerkis, A.; Hayashi, M.A.; Yamane, T.; Kerkis, I. Properties of cell penetrating peptides (CPPs). IUBMB Life 2006, 58, 7-13. https://doi.org/10.1080/15216540500494508

25. Caron, N.J.; Torrente, Y.; Camirand, G.; Bujold, M.; Chapdelaine, P.; Leriche, K.; Bresolin, N.; Tremblay, J.P. Intra-cellular delivery of a Tat-eGFP fusion protein into muscle cells. Mol. Ther. 2001, 3, 310-318. https://doi.org/10.1006/mthe.2001.0279

26. Derossi, D.; Chassaing, G.; Prochiantz, A. Trojan peptides: the penetrating system for intracellular delivery. Trends Cell Biol. 1998, 8, 84-87. https://doi.org/10.1016/S0962-8924(98)80017-2

27. Nascimento, F.D.; Hayashi, M.A.; Kerkis, A.; Oliveira, V.; Oliveira, E.B.; Rádis-Baptista, G.; Nader, H.B.; Yamane, T.; Tersariol, I.L.; Kerkis, I. Crotamine mediates gene delivery into cells through the binding to heparan sulfate pro-teoglycans. J. Biol. Chem. 2007, 282, 21349-21360. https://doi.org/10.1074/jbc.M604876200

28. Harada, H.; Kizaka-Kondoh, S.; Hiraoka, M. Antitumor protein therapy; application of the protein transduction domain to the development of a protein drug for cancer treatment. Breast Cancer 2006, 13, 16-26. https://doi.org/10.2325/jbcs.13.16

29. Campeiro, J.D.; Marinovic, M.P.; Carapeto, F.C.; Dal Mas, C.; Monte, G.G.; Carvalho Porta, L.; Nering, M.B.; Oliveira, E.B.; Hayashi, M.A.F. Oral treatment with a rattlesnake native toxin crotamine efficiently inhibits the tumor growth with no potential toxicity for the host animal. Amino Acids 2018, 50, 267-278. https://doi.org/10.1007/s00726-017-2513-3

30. Nascimento, F.D.; Sancey, L.; Pereira, A.; Rome, C.; Oliveira, V.; Oliveira, E.B.; Nader, H.B.; Yamane, T.; Kerkis, I.; Tersariol, I.L.; Coll, J.L.; Hayashi, M.A.F. The natural cell-penetrating peptide crotamine targets tumos tissue in vivo and triggers a lethal calcium-dependent pathway in cultured cells. Mol. Pharm. 2012, 9, 211-221. https://doi.org/10.1021/mp2000605

31. Feng, J.; Zhao, J.; Hao, F.; Chen, C.; Bhakoo, K.; Tang, H. NMR-based metabonomics analyses of the effects of ul-tra-small super paramagnetic particles of iron oxide (USPIO) on macrophage metabolism. J. Nanoparticle Res. 2011, 13:2049-2062.

32. Feng, J.; Li, J.; Wu, H.; Chen, Z. Metabolic responses of HeLa cells to silica nanoparticles by NMR-based metabo-lomic analyses. Metabolomics 2013, 9, 874. https://doi.org/10.1007/s11306-013-0499-8

33. Oliveira, A.B.; de Moraes, F.R.; Candido, N.M.; Sampaio, I.; Paula, A.S.; de Vasconcellos, A.; Silva, T.C.; Miller, A.H.; Rahal, P.; Nery, J.G.; Calmon, M.F. Metabolic Effects of Cobalt Ferrite Nanoparticles on Cervical Carcinoma Cells and Nontumorigenic Keratinocytes. J. Proteome Res. 2016, 15, 4337-4348. https://doi.org/10.1021/acs.jproteome.6b00411 
34. Xia, J.; Sinelnikov, I.V.; Han, B.; Wishart, D.S. MetaboAnalyst 3.0--making metabolomics more meaningful. Nucl. Acids Res. 2015, 43(W1), W251-7. https://doi.org/10.1093/nar/gkv380

35. Wishart, D.S.; Jewison, T.; Guo, A.C.; Wilson, M.; Knox, C.; Liu, Y.; Djoumbou,, Y.; Mandal, R.; Aziat, F.; Dong, E.; Bouatra, S.; Sinelnikov, I.; Arndt, D.; Xia, J.; Liu, P.; Yallou, F.; Bjorndahl, T.; Perez-Pineiro, R.; Eisner, R.; Allen, F.; Neveu, V.; Greiner, R.; Scalbert, A. HMDB 3.0-The Human Metabolome Database in 2013. Nucl. Acids Res. 2013, 41(Database issue), D801-7. https://doi.org/10.1093/nar/gks1065

36. Mardinoglu, A.; Nielsen, J. Systems medicine and metabolic modelling. J. Intern. Med. 2012, 271, 14254. https://doi.org/10.1111/j.1365-2796.2011.02493.x

37. Ghaffari, P.; Mardinoglu, A.; Asplund, A.; Shoaie, S.; Kampf, C.; Uhlen, M.; Nielsen, J. Identifying antigrowth fac-tors for human cancer cell lines through genome-scale metabolic modeling. Sci. Rep. 2015, 5, 8183. https://doi.org/10.1038/srep08183

38. Cottret, L.; Wildridge, D.; Vinson, F.; Barrett, M.P.; Charles, H.; Sagot, M.F.; Jourdan, F. MetExplore: a web server to link metabolomic experiments and genome-scale metabolic networks. Nucl. Acids Res. 2010, 38(Web Server issue), W132-7. https://doi.org/10.1093/nar/gkq312

39. Ferreira, L.M. Cancer metabolism: the Warburg effect today. Exp. Mol. Pathol. 2010, 89, 372-80. https://doi.org/10.1016/j.yexmp.2010.08.006

40. DeBerardinis, R.J.; Chandel, N.S. Fundamentals of cancer metabolism. Sci. Adv. 2016, 2, e1600200. https://doi.org/10.1126/sciadv.1600200

41. Cameron, M.E.; Yakovenko, A.; Trevino, J.G. Glucose and Lactate Transport in Pancreatic Cancer: Glycolytic Metab-olism Revisited. J. Oncol. 2018, 6214838. https://doi.org/10.1155/2018/6214838

42. Vaupel, P.; Schmidberger, H.; Mayer, A. The Warburg effect: essential part of metabolic reprogramming and central contributor to cancer progression. Int. J. Radiat. Biol. 2019, 1, 1-8. https://doi.org/10.1080/09553002.2019.1589653

43. Chen, X.S.; Li, L.Y.; Guan, Y.D.; Yang, J.M.; Cheng, Y. Anticancer strategies based on the metabolic profile of tumor cells: therapeutic targeting of the Warburg effect. Acta Pharmacol. Sin. 2016, 37, 1013-9. https://doi.org/10.1038/aps.2016.47

44. Schug, Z.T.; Peck, B.; Jones, D.T.; Zhang, Q.; Grosskurth, S.; Alam, I.S.; Goodwin, L.M.; Smethurst, M.; Blyth, K.; McGarry, L.; James, E.; Shanks, G.; Saunders, R.E.; Jiang, M.; Howell, M.; Lassailly, F.; Thin, M.Z.; Spencer-Dene, B.; Stamp, G.; van den Broek, N.J.F.; Mackay, G.; Bulusu, V.; Kamphorst, J.J.; Tardito, S.; Strachan, D.; Harris, A.L.; Aboagye, E.O.; Critchlow, S.E.; Wakelam, M.J.O.; Schulze, A.; Gottlieb, E. AcetylCoA synthetase 2 promotes acetate utilization and maintains cancer cell growth under metabolic stress. Cancer Cell. 2015, 27, 57-71. https://doi.org/10.1016/j.ccell.2014.12.002

45. Martinez-Reyes, I.; Diebold, L.P.; Kong, H.; Schieber, M.; Huang, H.; Hensley, C.T.; Mehta, M.M.; Wang, T.; Santos, J.H.; Woychik, R.; Dufour, E.; Spelbrink, J.N.; Weinberg, S.E.; Zhao, Y.; DeBerardinis, R.J.; Chandel, N.S. TCA cycle and mitochondrial membrane potential are necessary for diverse biological functions. Mol. Cell 2016, 61, 199-209. https://doi.org/10.1016/j.molcel.2015.12.002

46. Anderson, N.M.; Mucka, P.; Kern, J.G.; Feng, H. The emerging role and targetability of the TCA cycle in cancer me-tabolism. Protein Cell 2017, 9, 216-237. https://doi.org/10.1007/s13238-017-0451-1

47. Adekola, K.; Rosen, S.T.; Shanmugam, M. Glucose transporters in cancer metabolism. Curr. Opin. Oncol. 2012, 24, 650-4. https://doi.org/10.1097/CCO.0b013e328356da72

48. Jóźwiak, P.; Krześlak, A.; Bryś Lipińska, A. Glucose-dependent glucose transporter 1 expression and its impact on viability of thyroid cancer cells. Oncol. Rep. 2015, 33, 913-920. https://doi.org/10.3892/or.2014.3673 
49. Labak, C.M.; Wang, P.Y.; Arora, R.; Guda, M.; Asuthkar, S.; Tsung, A.J.; Velpula, K.K. Glucose transport: meeting the metabolic demands of cancer, and applications in glioblastoma treatment. Am. J. Cancer Res. 2016, 6, 1599-1608.

50. Zhao, S.; Torres, A.; Henry, R.A.; Trefely, S.; Wallace, M.; Lee, J.V.; Carrer, A.; Sengupta, A.; Campbell, S.L.; Kuo, Y.M.; Frey, A.J.; Meurs, N.; Viola, J.M.; Blair, I.A.; Weljie, A.M.; Metallo, C.M.; Snyder, N.W.; Andrews, A.J.; Wellen, K.E. ATP-Citrate Lyase Controls a Glucose-to-Acetate Metabolic Switch. Cell Rep. 2016, 17, 1037-1052. https://doi.org/10.1016/j.celrep.2016.09.069

51. Lakhter, A.J.; Hamilton, J.; Konger, R.L.; Brustovetsky, N.; Broxmeyer, H.E.; Naidu, S.R. Glucoseindependent Ace-tate Metabolism Promotes Melanoma Cell Survival and Tumor Growth. J. Biol. Chem. 2016, 291, 21869-21879. https://doi.org/10.1074/jbc.M115.712166

52. Comerford, S.A.; Huang, Z.; Du, X.; Wang, Y.; Cai, L.; Witkiewicz, A.K.; Walters, H.; Tantawy, M.N.; Fu, A.; Man-ning, H.C.; Horton, J.D.; Hammer, R.E.; McKnight, S.L.; Tu, B.P. Acetate dependence of tumors. Cell 2014, 159, 1591-602. https://doi.org/10.1016/j.cell.2014.11.020

53. Yoshii, Y.; Furukawa, T.; Yoshii, H.; Mori, T.; Kiyono, Y.; Waki, A.; Kobayashi, M.; Tsujikawa, T.; Kudo Okazawa, H.; Yonekura, Y.; Fujibayashi, Y. Cytosolic acetyl-CoA synthetase affected tumor cell survival under hypoxia: the pos-sible function in tumor acetyl-CoA/acetate metabolism. Cancer Sci. 2009a 100, 821827. https://doi.org/10.1111/j.1349-7006.2009.01099.X

54. Yoshii, Y.; Waki, A.; Furukawa, T.; Kiyono, Y.; Mori, T.; Yoshii, H.; Kudo, T.; Okazawa, H.; Welch, M.J.; Fujibayashi, Y. Tumor uptake of radiolabeled acetate reflects the expression of cytosolic acetylCoA synthetase: implications for the mechanism of acetate PET. Nucl. Med. Biol. 2009b 36, 771-777. https://doi.org/10.1016/j.nucmedbio.2009.05.006

55. Mashimo, T.; Pichumani, K.; Vemireddy, V.; Hatanpaa, K.J.; Singh, D.K.; Sirasanagandla, S.; Nannepaga, S.; Picci-rillo, S.G.; Kovacs, Z.; Foong, C.; Huang, Z.; Barnett, S.; Mickey, B.E.; DeBerardinis, R.J.; Tu, B.P.; Maher, E.A.; Bachoo, R.M. Acetate is a bioenergetic substrate for human glioblastoma and brain metastases. Cell 2014, 159, 1603-14. https://doi.org/10.1016/j.cell.2014.11.025

56. Yang, C.; Ko, B.; Hensley, C.T.; Jiang, L.; Wasti, A.T.; Kim, J.; Sudderth, J.; Calvaruso, M.A.; Lumata, L.; Mitsche, M.; Rutter, J.; Merritt, M.E.; DeBerardinis, R.J. Glutamine oxidation maintains the TCA cycle and cell survival during impaired mitochondrial pyruvate transport. Mol. Cell 2014, 56, 414-424. https://doi.org/10.1016/j.molcel.2014.09.025

57. Ghaffari, P.; Mardinoglu, A.; Nielsen, J. Cancer Metabolism: A Modeling Perspective. Front. Physiol. 2015, 6, 382. https://doi.org/10.3389/fphys.2015.00382

58. Epstein, T.; Gatenby, R.A.; Brown, J.S. The Warburg effect as an adaptation of cancer cells to rapid fluctuations in energy demand. PLoS One 2017, 12, e0185085. https://doi.org/10.1371/journal.pone.0185085 59. Kim, S.Y. Cancer Energy Metabolism: Shutting Power off Cancer Factory. Biomol. Ther. (Seoul) 2018, 26, 39-44. https://doi.org/10.4062/biomolther.2017.184

60. Amelio, I.; Cutruzzolá, F.; Antonov, A.; Agostini, M.; Melino, G. Serine and glycine metabolism in cancer. Trends Biochem. Sci. 2014, 39, 191-8. https://doi.org/10.1016/j.tibs.2014.02.004

61. Fadaka, A.; Ajiboye, B.; Ojo, O.; Adewale, O.; Olayide, I.; Emuowhochere, R. Biology of glucose metabolization in cancer cells. J. Oncol. Sci. 2017, 3, 45-51. https://doi.org/10.1016/j.jons.2017.06.002

62. Warburg O, Wind F, Negelein E. The metabolism of tumors in the body. J. Gen. Physiol. 1927, 8, 519-30. https://doi.org/10.1085/jgp.8.6.519

63. Liberti, M.V.; Locasale, J.W. The Warburg Effect: How Does it Benefit Cancer Cells? Trends Biochem. Sci. 2016, 41, 211-218. https://doi.org/10.1016/j.tibs.2015.12.001 
64. Fu, Y.M.; Yu, Z.X.; Lin, H.; Fu, X.; Meadows, G.G. Selective amino acid restriction differentially affects the motility and directionality of DU145 and PC3 prostate cancer cells. J. Cell Physiol. 2008, 217, 184-93. https://doi.org/10.1002/jcp.21490

65. Kulcsár, G.; Gaál, D.; Kulcsár, P.I.; Schulcz, Á.; Czömpöly, T. A mixture of amino acids and other small molecules present in the serum suppresses the growth of murine and human tumors in vivo. Int. J. Cancer 2013, 132, 1213-21. https://doi.org/10.1002/ijc.27756

66. Bonfili, L.; Cecarini, V.; Cuccioloni, M.; Angeletti, M.; Flati, V.; Corsetti, G.; Pasini, E.; Dioguardi, F.S.; Eleuteri, A.M. Essential amino acid mixtures drive cancer cells to apoptosis through proteasome inhibi-tion and autophagy activation. FEBS J. 2017, 284, 1726-1737. https://doi.org/10.1111/febs.14081

67. Fu, Y.M.; Lin, H.; Liu, X.; Fang, W.; Meadows, G.G. Cell death of prostate cancer cells by specific amino acid re-striction depends on alterations of glucose metabolism. J. Cell. Physiol. 2010, 224, 491-500. https://doi.org/10.1002/jcp.22148

68. Shyh-Chang, N.; Locasale, J.W.; Lyssiotis, C.A.; Zheng, Y.; Teo, R.Y.; Ratanasirintrawoot, S.; Zhang, J.; Onder, T.; Unternaehrer, J.J.; Zhu, H.; Asara, J.M.; Daley, G.Q.; Cantley, L.C. Influence of threonine metabolism on S-adenosylmethionine and histone methylation. Science 2013, 339, 222-6. https://doi.org/10.1126/science.1226603

69. Krall, A.S.; Xu, S.; Graeber, T.G.; Braas, D.; Christofk, H.R. Asparagine promotes cancer cell proliferation through use as an amino acid exchange factor. Nat. Commun. 2016, 29, 11457. https://doi.org/10.1038/ncomms11457

70. Blomback, B. Methods in Enzymology (Hirs C., editor. ed) Academic Press New York. Vol. 11, 1967, pp. 389-411.

71. Liu, Y.D.; Goetze, A.M.; Bass, R.B.; Flynn, G.C. N-terminal glutamate to pyroglutamate conversion in vivo for human IgG2 antibodies. J. Biol. Chem. 2011, 286, 11211-7. https://doi.org/10.1074/jbc.M110.185041 72. Rink, R.; Arkema-Meter, A.; Baudoin, I.; Post, E.; Kuipers, A.; Nelemans, S.A.; Akanbi, M.H.; Moll, G.N. To protect peptide pharmaceuticals against peptidases. J. Pharmacol. Toxicol. Methods 2010, 61, 210-218. https://doi.org/10.1016/j.vascn.2010.02.010

73. Traverso, N.; Ricciarelli, R.; Nitti, M.; Marengo, B.; Furfaro, A.L.; Pronzato, M.A.; Marinari, U.M.; Domenicotti, C. Role of glutathione in cancer progression and chemoresistance. Oxid. Med. Cell Longev. 2013, 972913. https://doi.org/10.1155/2013/972913

74. Hussain, S.P.; Hofseth, L.J.; Harris, C.C. Radical causes of cancer. Nat. Rev. Cancer 2003, 3, $276-85$. https://doi.org/10.1038/nrc1046

75. Townsend, D.M.; Tew, K.D. The role of glutathione-S-transferase in anti-cancer drug resistance. Oncogene 2003, 22, 7369-75. https://doi.org/10.1038/sj.onc.1206940

76. Katagiri, R.; Goto, A.; Nakagawa, T.; Nishiumi, S.; Kobayashi, T.; Hidaka, A.; Budhathoki, S.; Yamaji, T.; Sawada, N.; Shimazu, T.; Inoue, M.; Iwasaki, M.; Yoshida, M.; Tsugane, S. Increased Levels of BranchedChain Amino Acid Associated With Increased Risk of Pancreatic Cancer in a Prospective Case-Control Study of a Large Cohort. Gas-troenterology 2018, 155, 1474-1482. https://doi.org/10.1053/j.gastro.2018.07.033

77. Neinast, M.; Murashige, D.; Arany, Z. Branched Chain Amino Acids. Annu. Rev. Physiol. 2019, 81, 139164. https://doi.org/10.1146/annurev-physiol-020518-114455

78. Ananieva EA. Wilkinson AC. Branched-chain amino acid metabolism in cancer. Curr. Opin. Clin. Nutr. Metab. Care 2018, 21, 64-70. https://doi.org/10.1097/MCO.0000000000000430 
79. Selwan, E.M.; Edinger, A.L. Branched chain amino acid metabolism and cancer: the importance of keeping things in context. Transl. Cancer Res. 2016, 6(Suppl. 3), S578-S584. https://doi.org/10.21037/tcr.2017.05.05

80. Zhao, S.; Xu, W.; Jiang, W.; Yu, W.; Lin, Y.; Zhang, T.; Yao, J.; Zhou, L.; Zeng, Y.; Li, H.; Li, Y.; Shi, J.; An, W.; Han-cock, S.M.; He, F.; Qin, L.; Chin, J.; Yang, P.; Chen, X.; Lei, Q.; Xiong, Y.; Guan, K.L. Regulation of cellular metabolism by protein lysine acetylation. Science 2010, 327, 1000-1004. https://doi.org/10.1126/science.1179689

81. Baeza, J.; Smallegan, M.J.; Denu, J.M. Mechanisms and dynamics of Protein Acetylation in Mitochondria. Trends Biochem. Sci. 2016, 41, 231-244. https://doi.org/10.1016/j.tibs.2015.12.006

82. Peng, C.; Lu, Z.; Xie, Z.; Cheng, Z.; Chen, Y.; Tan, M.; Luo, H.; Zhang, Y.; He, W.; Yang, K.; Zwaans, B.M.; Tishkoff, D.; Ho, L.; Lombard, D.; He, T.C.; Dai, J.; Verdin, E.; Ye, Y.; Zhao, Y. The first identification of lysine malonylation substrates and its regulatory enzyme. Mol. Cell. Proteom. 2011, 10, M111.012658. https://doi.org/10.1074/mcp.M111.012658

83. Kaypee, S.; Sudarshan, D.; Shanmugam, M.K.; Mukherjee, D.; Sethi, G.; Kundu, T.K. Aberrant lysine acetylation in tumorigenesis: Implications in the development of therapeutics. Pharmacol. Ther. 2016, 162, 98-119. https://doi.org/10.1016/j.pharmthera.2016.01.011

84. Budczies, J.; Brockmöller, S.F.; Müller, B.M.; Barupal, D.K.; Richter-Ehrenstein, C.; Kleine-Tebbe, A.; Griffin, J.L.; Orešič, M.; Dietel, M.; Denkert, C.; Fiehn, O. Comparative metabolomics of estrogen receptor positive and estro-gen receptor negative breast cancer: alterations in glutamine and beta-alanine metabolism. J. Proteom. 2013, 94, 279-88. https://doi.org/10.1016/j.jprot.2013.10.002

85. Brosnan, M.E.; Brosnan, J.T. Formate: The Neglected Member of One-Carbon Metabolism. Annu. Rev. Nutr. 2016, 36, 369-88. https://doi.org/10.1146/annurev-nutr-071715-050738

86. Wang, H.; Wang, L.; Zhang, H.; Deng, P.; Chen, J.; Zhou, B.; Hu, J.; Zou, J.; Lu, W.; Xiang, P.; Wu, T.; Shao, X.; Li, Y.; Zhou, Z.; Zhao, Y.L. 1H NMR-based metabolic profiling of human rectal cancer tissue. Mol. Cancer 2013, 12, 121. https://doi.org/10.1186/1476-4598-12-121

87. Wang, L.; Chen, J.; Chen, L.; Deng, P.; Bu, Q.; Xiang, P.; Li, M.; Lu, W.; Xu, Y.; Lin, H.; Wu, T.; Wang, H.; $\mathrm{Hu}$, J.; Shao, X.; Cen, X.; Zhao, Y.L. 1H-NMR based metabonomic profiling of human esophageal cancer tissue. Mol. Cancer 2013, 12, 25. https://doi.org/10.1186/1476-4598-12-25 


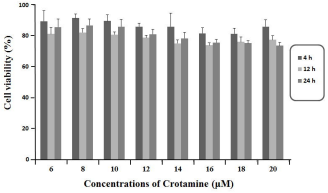




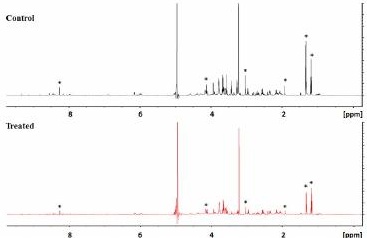




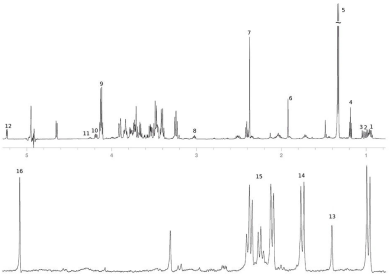


a) FULL SPECTRA
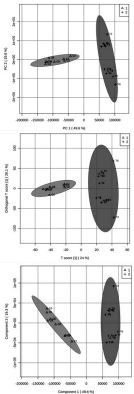

b) METABOLITE CONC.

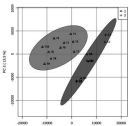

5

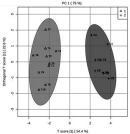

$\frac{9}{5}$

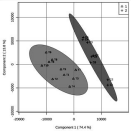




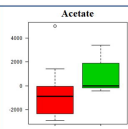

Crotamine Costrol

Glucose

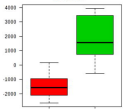

Crotamine Control

Leacine

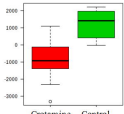

Crotamine Control

$\pi$-Methylhistidine

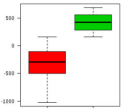

Crotamine Costrol

Threonine

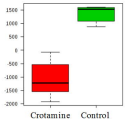

Cortamine Control
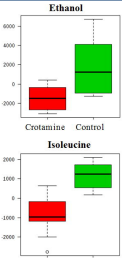

Crotamine Control

Lysine

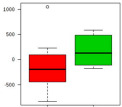

Crotamine Control

Pyruglutamate

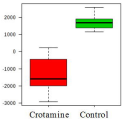

Tyrosine

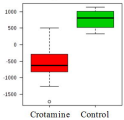

Formate

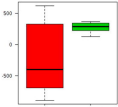

Crotamine Control

Lactate

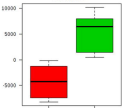

Crotamine Control

Phenylalanine

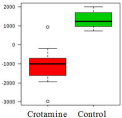

Pyruvate

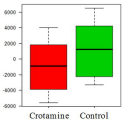

Valine

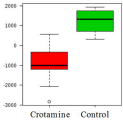


a)

Metabolite Importsone

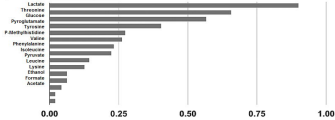

b)
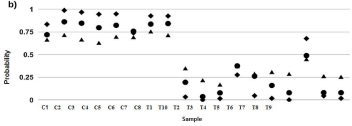

- SVM APLS.DA * Randomforest 


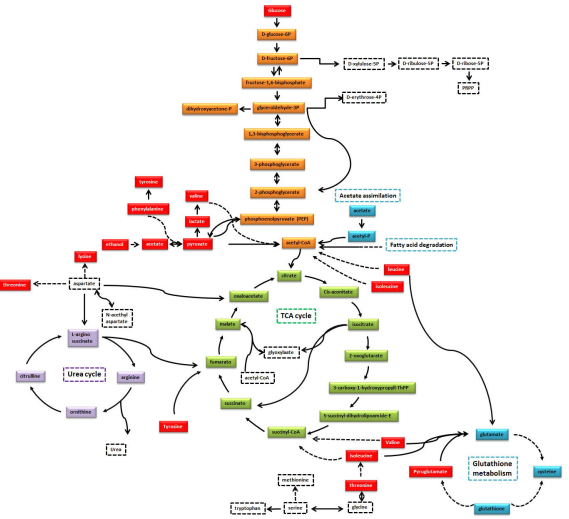

